\title{
Bir Yenidoğanda PCR ile Tanı Konulan Listeria monocytogenes Menenjiti
}

\author{
A Listeria monocytogenes Newborn Meningitis Diagnosed by PCR \\ ${ }^{1}$ Meltem KARABAY, ${ }^{2}$ İrem TÜRKOĞLU KUZU, ${ }^{3}$ Mehmet KÖROĞLU, ${ }^{1}$ İbrahim CANER \\ ${ }^{1}$ Sakarya Üniversitesi Tıp Fakültesi, Çocuk Sağlığı ve Hastalıkları Anabilim Dalı, Neonatoloji Bilim Dalı, Sakarya, Türkiye \\ ${ }^{2}$ Sakarya Üniversitesi Tıp Fakültesi, Çocuk Sağlığı ve Hastalıkları Anabilim Dalı, Sakarya, Türkiye \\ ${ }^{3}$ Sakarya Üniversitesi Tıp Fakültesi, Tıbbi Mikrobiyoloji Anabilim Dalı, Sakarya, Türkiye \\ Meltem Karabay: https://orcid.org/0000-0001-7105-7176 \\ İrem Türkoğlu Kuzu: https://orcid.org/0000-0002-2398-8571 \\ Mehmet Köroğlu: https://orcid.org/0000-0001-8101-1104 \\ İbrahim Caner: https://orcid.org/0000-0002-6756-122X
}

\section{ÖZ}

Listeria monocytogenes yenidoğan döneminde sepsis, pnömoni ve menenjite neden olan Gram pozitif bir bakteridir. Hastamız, ateş, emmede azalma şikayetleriyle kliniğimize yatırıldı. Hastanın yapılan muayenesinde genel durumu kötü, ateşi aksiller $38,8^{\circ} \mathrm{C}$, emmesi azalmış, fontaneli bombeydi. Hastaya geç neonatal sepsis ve menenjit ön tanısıyla ampisilin, sefotaksim başlandı. Hastanın laboratuvar incelemesinde; kanda lökosit 17.1x103/ $\mathrm{mm}^{3}$, CRP $6 \mathrm{mg} / \mathrm{dl}$, prokalsitonin 0,229 ng/ml. Beyin omurilik sıvisında (BOS) mikroprotein $291 \mathrm{mg} / \mathrm{dl}$, glukoz $27 \mathrm{mg} / \mathrm{dl}$ ölçüldü. Hastaya yapılan lomber ponksiyonda BOS basıncı artmış, görünümü bulanık ve hücre say1mında $\mathrm{mm}^{3}$ de 800 hücre tespit edildi. Gram boyamada bakteri görülmedi. BOS ve Kan kültürü örneklerinde üreme olmadı. Polimeraz zincir reaksiyonu (PZR) ile BOS'ta L. monocytogenes DNA's1 saptand1. Bu yazıda kan ve BOS kültürleri, Gram boyama sonuçları ve akut faz reaktanları negatif olan bir olguda PZR ile tanısı konulan Listeria menenjiti olgusunun sunulması amaçlanmıştır. Anahtar Kelimeler: Listeria monocytogenes, menenjit, yenidoğan

\begin{abstract}
Listeria monocytogenes is a Gram positive bacterium that causes sepsis, pneumonia and meningitis in the neonatal period. Our patient was admitted to our clinic with complaints of fever and decreased sucking. In the examination of the patient, his general condition was poor, his fever was $38.8^{\circ} \mathrm{C}$ axillary, his sucking was decreased, and he was bomb with fontanel. Ampicillin and cefotaxime were started with the pre-diagnosis of late neonatal sepsis and meningitis. In the laboratory examination of the patient; leukocyte $17.1 \times 103 / \mathrm{mm}^{3}$, CRP $6 \mathrm{mg} / \mathrm{dl}$, procalcitonin $0.229 \mathrm{ng} / \mathrm{ml}$. Microprotein $291 \mathrm{mg} / \mathrm{dl}$ and glucose $27 \mathrm{mg} /$ dl were measured in the cerebrospinal fluid (CSF). In lumbar puncture, CSF pressure was increased, its appearance was blurred and 800 cells per $\mathrm{mm}^{3}$ were detected in cell count. No bacteria were seen in the Gram stain. There was no growth in the culture of CSF and blood samples. $L$. monocytogenes DNA was detected in CSF by PCR. In this article, it is aimed to present a case of Listeria meningitis diagnosed by PCR in a case whose blood and CSF cultures, Gram staining results and acute phase reactants were negative.
\end{abstract}

Keywords: Listeria monocytogenes, meningitis, newborn

\footnotetext{
Sorumlu Yazar / Corresponding Author:

Meltem Karabay

Anabilim Dalı, Neonatoloji Bilim Dalı, Sakarya, Türkiye

Tel: +90 5056702693

E-mail: meltemkarabay@yahoo.com
}

Yayın Bilgisi / Article Info:

Gönderi Tarihi/ Received: 04/01/2021

Sakarya Üniversitesi Tıp Fakültesi, Çocuk Sağlığı ve Hastalıkları Kabul Tarihi/ Accepted: 04/04/2021

Atıf/ Cited: Karabay M ve ark. Bir Yenidoğanda PCR ile Tanı Konulan Listeria monocytogenes Menenjiti. Online Türk Sağlık Bilimleri Dergisi, 2021;6(2):315-317. doi: 10.26453/otjhs.853879

\section{Gíriş}

Listeria monocytogenes; yenidoğanlarda, yaşlılarda, hamilelerde ve immün yetmezlikli hastalarda ciddi hastalığa neden olur. ${ }^{1,2} \quad L$. monocytogenes yenidoğanlarda menenjitin en sik üç sebebinden biridir. ${ }^{3}$ Bakteri; hareketli, sporsuz, katalaz pozitif, oksidaz negatif, gram pozitif koko-basildir. Bakterinin üreme ${ }_{1 S 1 S 1} \quad 4-37{ }^{\circ} \mathrm{C}$ arasında değişir. $L$. monocytogenes, mononükleer hücrelerde yaşamını sürdürür, hücreler arasında yayılabilir ve böylece 
savunma sisteminden kaçar. ${ }^{4}$

İnsana kontamine et, çiğ sebze, süt ve süt ürünleri ile gıda kaynaklı bulaşabilir. Buzdolabı sıcaklığında üreyebildiğinden saklanan gıdalara kolayca bulaşır. ${ }^{5}$ Hayvanlarla direkt teması olan insanlarda risk daha fazladır. Toplumda nadir görülen hastalık nedeni olmasına rağmen; yenidoğanlar, hamileler, yaşlilar, immün yetmezlik olanlarda ölümcül olabilir. ${ }^{2,6}$

Plasentadan ya da doğum sırasında vajinal kanaldan alınan basil bebeklerde neonatal listeriozis enfeksiyonuna yol açabilir. ${ }^{2}$ Neonatal listeriozisin bulgularının ortaya çıkış zamanına göre erken ve geç başlangıçlı olarak sınıflandırılır. Yenidoğanlardaki $L$. monocytogenes enfeksiyonlarında, erken dönemde sepsis, geç neonatal dönemde ise menenjit ön plandadır. İntrauterin dönemde geçirenlerde granülomatosis infantiseptika tablosuyla yaygın enfeksiyon meydana gelebilir. Özellikle karaciğer ve dalak gibi birçok organda yaygın apseler veya granülomlar görülebilir. ${ }^{2,6}$

Bakteriyel menenjit etkenleri içinde en zor üretilen bakterilerden biridir. Birçok olguda bu bakterinin üretilmesi mümkün olmamaktadır. Bu yazıda PZR ile tanısı konan L. monocytogenes menenjitinin sunulması amaçlanmıştır.

\section{OLGU SUNUMU}

Hayvancılıkla uğraşan 25 yaşındaki annenin ikinci gebeliğinden ikinci yaşayan olarak sezaryenle doğan, 3600 gr doğum ağırlığında, term erkek bebek, postnatal onuncu gününde; iki gündür ateş ve emmede azalma şikayetiyle çocuk acile başvurdu. Hastanın yapılan fizik muayenesinde genel durumu kötü, huzursuz ve ajite idi. Ateşi aksiller $38,8{ }^{\circ} \mathrm{C}$, emmesi azalmış, fontaneli bombe ve kapiller dolum zamanı uzamıştı. Solunum sesleri doğaldı. Hastada başka patolojik bulgu saptanmadi. Geç neonatal sepsis ve merkezi sinir sistemi enfeksiyonu ön tanısı ile hasta yenidoğan yoğun bakım ünitesine yatırıldı. Hastaya ampisilin, sefotaksim, sıvı-elektrolit ve dolaşım destek tedavisine başlandı. Aileden alınan anamnezde annenin antenatal izleminde herhangi bir özellik saptanmamış olup, enfeksiyon öyküsünün ve erken membran rüptürünün olmadığı, annenin son trimesterde ve doğumdan sonra hayvancılıkla uğraşılan bir evde yaşadığı öğrenildi. Hastanın laboratuvar incelemesinde; kanda lökosit $17,1 \times 10^{3} / \mathrm{mm}^{3}$, CRP 6 $\mathrm{mg} / \mathrm{dl}$, prokalsitonin $0,229 \mathrm{ng} / \mathrm{ml}$, beyin omurilik sivisı (BOS)' nda mikroprotein $291 \mathrm{mg} / \mathrm{dl}$, glukoz $27 \mathrm{mg} / \mathrm{dl}$ (eş zamanlı kan şekeri $80 \mathrm{mg} / \mathrm{dl}$ ) ölçüldü. Hastanın yatışından sonra alınan diğer CRP'leri sırasiyla 3,29 mg/dl (24. saat), 0,24 mg/dl (3. gün), 0,25 mg/dl (7. gün) idi. İlk gün alınan BOS örneği bulanık ve basıncı artmıştı. Thoma lamındaki mikroskopisinde $\mathrm{mm}^{3}$ de 800 hücre, Gram boyamasinda her sahada 3-4 polimorf nüveli lökosit, 6-8 lenfosit görülürken bakteri görülmedi. BOS ve kan örneklerinde üreme olmadı. Ancak BOS'un gerçek zamanlı PZR (Fast-track diagnostics meningitis multiplex PCR kit Luxemburg) incelemesinde $L$. monocytogenes DNA's1 pozitif olarak saptand1. Hastanın karaciğer ve böbrek fonksiyonları normaldi. Tam idrar tahlilinde patolojik bulgu saptanmadi. Hastaya L. monocytogenes menenjiti tanisı ile ampisilin ve gentamisin 21 gün süreyle verildi. Yat1şı sırasında çekilen beyin Manyetik Rezonans Görüntüleme, transfontanel ultrason ve tüm batın ultrason tetkiklerinde patoloji saptanmadi. Hasta şifa ile taburcu edildi.

\section{TARTIŞMA VE SONUÇ}

L. monocytogenes mononükleer fagositer hücrelere invazyon gösterir ve hücreden hücreye yayılır. Listeria enfeksiyonu riski gebelerde daha yüksektir. Gebelerde asemptomatik olabildiği gibi sadece grip semptomları gibi baş, kas, sırt ağrısı, ateş, bulantı, kusma gibi non-spesifik belirtilerle seyredebilir. Özellikle hayvancılığın yaygın olduğu bölgelerde, hamile kadınların üçüncü trimesterinde, ürogenital sistemde L. monocytogenes kolonizasyonu araştırılmalıdır. Yenidoğan döneminde L. monocytogenes sepsis, menenjit, pnömoni şeklinde ortaya çıkabilir. Ateş, huzursuzluk, emmede azalma, uykuya meyil, kusma, konvülziyon gibi bulgular verebilir. BOS incelemesinde pleositoz, protein yükselmesi, glukoz azalması genellikle görülür., ${ }^{2,7}$

Listeria hayvancılıkla uğraşanlarda daha sık enfeksiyona neden olmaktadır. Özellikle süt kaynaklı gıdaların üretiminde çalışanlar Listeria enfeksiyon riski altındadır. $^{6} \mathrm{Bu}$ nedenle menenjitle başvuran yenidoğan annelerinin ne iş yaptığının sorgulanması önem taşımaktadır.

L. monocytogenes, bakteriyel gastroenterit vakalar1nın \%1'inden daha azını oluşturur. Gebelikte Listeria varlığında ateş, titreme, sırt ağrısı ortaya çıkabilir. Klinik olarak hafif olabilir, tedavi olmadan düzelebilir ve kan kültürlerinde üretilemezse tanı koyulamayabilir. ${ }^{3}$

Hastadan alınan BOS örneğinde basınç artmış, bulanık ve bol lökosit olmasına rağmen Gram boyama ile bakteri görülmedi. BOS ve kan kültüründe üreme olmadı. Listeria menenjitlerinde bakteri görülme olasılı̆̆ 1 1/3 olarak rapor edilmiştir. ${ }^{8}$ Bir araştırmada Listeria menenjitli bebeklerde sadece $\% 41$ oranında 
BOS kültürü pozitifliği gösterilmiştir. ${ }^{9}$ Ayrıca hastanın CRP düzeylerinde de belirgin yükseklik saptanmadi. Ancak BOS PZR ile L. monocytogenes pozitif saptand $1{ }^{4}$ Yapılan araştırmalarda da PZR' in kültürden daha duyarlı olduğu gösterilmiştir. ${ }^{10}$ Hastadan alınan örneklerde üreme olmaması, anneye verilen profilaktik antibiyotiklere bağlı olabileceği gibi bebeğe geldiğinde hemen başlanan antibiyotiklere bağ$l_{1}$ da olabilir. Zaten Listeria enfeksiyonları tüm menenjit etkenleri içinde üretme olasılığı en düşük olanıdır. Hastaya BOS PZR ile L. monocytogenes menenjit tanıs1 konulup 21 gün süreyle ampisilin ve gentamisin tedavisi verildi. Sonrasında şikayeti olmayan ve laboratuvar tetkikleri normal olan hasta şifa ile taburcu edildi. Olgumuzda olduğu gibi moleküler tekniklerin kullanılması, özellikle kültür negatif menenjitlerin tanısına değerli bir katkı sağlayabilir.

Sepsis ve menenjit tablosu ile başvuran yenidoğanlarda L. monocytogenes enfeksiyonu ayır1c1 tanıda düşünülmelidir. Bu olgularda karaciğer ve dalak gibi organlarda apse oluşabileceği unutulmamalıdır. BOS ve kan kültüründe etken aranmalıdır. Ancak kültürler negatif ise PZR testi etkeni göstermede iyi bir yöntemdir. Listerya menenjitinde ilk tercih ampisilin ve penisilindir. Seftriakson gibi üçüncü kuşak sefalosporinlerin Listerya tedavisinde yeri yoktur. Beta laktam alerjisi olanlarda kotrimaksazol bir alternatif olabilmektedir.

Etik Komite Onayı: Çalışmamız olgu sunumu olduğu için etik kurul onayı gerekmemektedir Hastaya bilgilendirilmiş gönüllü olur/onam formu imzalatılmiştır.

Çıkar Çatışması: Yazarlar çıkar çatışması bildirmemişlerdir.

Yazar Katkıları: Vaka izlemi - MK, İTK, İC; Veri Toplanması ve işlemesi - M.Kör; Yazıyı yazan MK.

Diğer: Bu yazının özeti 12-14 Mart 2020 tarihinde, İstanbul'da yapılan Çocuk Dostları Kongresinde poster özeti olarak sunulmuştur.

\section{KAYNAKLAR}

1. Shruthi Matle I, Mbatha KR, Madoroba E. A review of Listeria monocytogenes from meat and meat products: Epidemiology, virulence factors, antimicrobial resistance and diagnosis. Onderstepoort J Vet Res. 2020;87(1):1-20.

2. Chrétien R, Voide C, Bally F. Outbreak of listeriosis in Valais, 2020: review of causes of food contamination. Rev Med Suisse. 2020;16
(710):1926-1931.

3. Mylonakis E, Paliou M, Hohmann EL, Calderwood SB, Wing EJ. Listeriosis during pregnancy: a case series and review of 222 cases. Medicine (Baltimore). 2002 ;81(4):2609. doi: 10.1097/00005792-200207000-00002.

4. Brouwer MC, van de Beek D, Heckenberg SGB, Spanjaard L, de Gans J. Communityacquired Listeria monocytogenes meningitis in adults. Clin Infect Dis. 2006;43(10):1233-1238.

5. Akpolat NÖ, Elci S, Atmaca S, Gül K. Listeria monocytogenes in products of animal origin in Turkey. Vet Res Commun. 2004;28(7):561567.

6. Marth EH, Steele, J. Applied Dairy Microbiology. 2nd ed. Texas, TX: CRC Press; 2001.

7. Rugna G, Carra E, Bergamini F, et al. Distribution, virulence, genotypic characteristics and antibiotic resistance of Listeria monocytogenes isolated over one-year monitoring from two pig slaughterhouses and processing plants and their fresh hams. Int $\mathbf{J}$ Food Microbiol. 2021;336:108912.

8. Mylonakis E, Hohmann EL, Calderwood SB. Central nervous system infection with Listeria monocytogenes: 33 years' experience at a general hospital and review of 776 episodes from the literature. Medicine. 1998;77(5):313-336.

9. Armstrong RW, Fung PC. Brainstem encephalitis (rhombencephalitis) due to Listeria monocytogenes: Case report and review. Clin Infect Dis. 1993;16(5):689-702.

10. Leber AL, Everhart K, Balada-Llasat JM, et al. Multicenter evaluation of BioFire FilmArray meningitis/encephalitis panel for detection of bacteria, viruses, and yeast in cerebrospinal fluid specimens. J Clin Microbiol. 2016;54 (9):2251-2261. 